\title{
Design, Synthesis and Characterization of Some Novel benzamide derivatives and it's Pharmacological Screening
}

\author{
Akshay R. Yadav*, Shrinivas K. Mohite
}

Department of Pharmaceutical Chemistry, Rajarambapu College of Pharmacy, Kasegaon, Maharashtra, India Corresponding author E-mail:- akshayyadav24197@gmail.com

\section{ABSTRACT}

The new series of substituted $\mathrm{N}$-(phenylcarbamothioyl)benzamide derivatives (2a-2f) was designed, development and synthesized by using conventional and microwave method. In present work six different $\mathrm{N}$-(phenylcarbamothioyl)benzamide were synthesized. Substituted benzoyl chloride is converted into benzoyl isothiocyanate by esterification. Benzoyl isothiocyanate is converted into Substituted (phenylcarbamothioyl)benzamide by treating with substituted aniline. Confirmation of the chemical structure of the synthesized was substantiated by TLC, IR, 1H NMR, MS spectroscopy. Novel synthesized compounds screened for their in vivo and in-vitro anti-inflammatory studies and compound $2 \mathrm{f}$ shows promising anti-inflammatory activity.

Keywords: Benzamide, Microwave, Anti-Inflammatory Activity

\section{INTRODUCTION}

Benzamide used in medicinal as well as nonmedicinal activities in industry. Thiourea is organic compound having sulphur with the general formula $\left(\mathrm{R}_{1} \mathrm{R} 2 \mathrm{~N}\right)(\mathrm{R} 3 \mathrm{R} 4 \mathrm{~N}) \mathrm{C}=\mathrm{S}$. Thiourea and urea derivatives show a broad spectrum of biological activities as antiHIV, antiviral, HDL-elevating, antibacterial and analgesic properties. Acyl thiourea derivatives are well known for wide range of biological activities like bactericidal, fungicidal, herbicidal, insecticidal action and regulating activity for plant growth. Thiourea derivatives are exceptionally versatile building blocks for the synthesis of a variety of heterocyclic compounds. Diaryl thioureas exhibit significant antifungal activity against the plant pathogens. Acyl thioureas are well known for their superior pesticidal, fungicidal, antiviral, and regulating activity for plant growth. Thiourea derivatives have attracted great attention as versatile ligands in numerous applications. Benzamide is an aromatic amide that consists of benzene bearing a single carboxamido substituent. Over 30 drugs containing this functionality are in clinical use, including antihypertensive agent, antibacterial, antiprotozoal, antifungal, antiinflammatory, nonpeptidic vasopressin receptor antagonists and translation initiation inhibitors. Some important benzamide derivatives used as carbonic anhydrase inhibitors of commercial importance. "Green chemistry" is defined as the synthesis, design, development and application of chemical products to reduces hazardous substances. The application of green chemistry principles and practices renders regulation, control, clean-up, and remediation of the environment. Thus its benefits can be expressed in terms of economic impact. Therapeutically active and new drug constituents are needed for the treatment of different diseases. 


\section{RESULT AND DISCUSSION} The starting synthesized compound, aroyl resulting mixture refluxed and $\mathrm{N}$ isothiocyanate was prepared by the reaction of aroyl (phenylcarbamothioyl) benzamide were synthesized.

Table No. 1: In vitro anti-inflammatory activity of synthesized compounds measuring the percentage inhibition(2a-f)

\begin{tabular}{|c|c|c|c|c|}
\hline \multirow[t]{2}{*}{ Compound } & \multicolumn{2}{|c|}{$\begin{array}{c}\% \text { of inhibition of protein } \\
\text { denaturation }\end{array}$} & \multicolumn{2}{|c|}{ Viscosity (cps) } \\
\hline & $50 \mu \mathrm{g} / \mathrm{ml}$ & $100 \mu \mathrm{g} / \mathrm{ml}$ & $50 \mu \mathrm{g} / \mathrm{ml}$ & $100 \mu \mathrm{g} / \mathrm{ml}$ \\
\hline $2 a$ & 61.35 & 63.29 & 0.61 & 0.63 \\
\hline $2 b$ & 57.73 & 64.65 & 0.58 & 0.68 \\
\hline $2 c$ & 63.52 & 65.78 & 0.67 & 0.54 \\
\hline $2 d$ & 63.44 & 68.30 & 0.59 & 0.60 \\
\hline $2 e$ & 59.42 & 62.56 & 0.60 & 0.57 \\
\hline $2 f$ & 68.80 & 69.71 & 0.58 & 0.69 \\
\hline $\begin{array}{c}\text { Standard } \\
\text { (diclofenac) }\end{array}$ & 74.20 & 78.52 & 0.52 & 0.56 \\
\hline
\end{tabular}

Table No. 2: In vivo anti-inflammatory activity of synthesized compounds measuring the percentage inhibition

\begin{tabular}{|c|c|c|c|c|c|c|c|c|}
\hline \multirow{2}{*}{$\begin{array}{l}\text { Sr. } \\
\text { no }\end{array}$} & \multirow{2}{*}{$\begin{array}{l}\text { compoun } \\
\text { d }\end{array}$} & \multicolumn{7}{|c|}{$\%$ inhibition of paw volume } \\
\hline & & $0 \min$ & $30 \mathrm{~min}$ & $60 \mathrm{~min}$ & $90 \mathrm{~min}$ & $120 \mathrm{~min}$ & $150 \mathrm{~min}$ & $180 \mathrm{~min}$ \\
\hline 1 & Control & 3.8 & - & - & - & - & - & - \\
\hline 2 & $\begin{array}{c}\text { Standard } \\
\text { (diclofena } \\
\text { c) }\end{array}$ & 0.0 & 12.38 & 20.78 & 26.13 & 37.98 & 54.62 & 61.86 \\
\hline 3 & $2 a$ & 0.0 & 11.83 & 16.45 & 21.43 & 33.94 & 51.56 & 58.45 \\
\hline 4 & $2 b$ & 0.0 & 09.67 & 15.89 & 20.78 & 32.39 & 50.23 & 56.73 \\
\hline 5 & $2 c$ & 0.0 & 10.75 & 17.34 & 23.94 & 30.84 & 48.90 & 59.27 \\
\hline 6 & $2 \mathrm{~d}$ & 0.0 & 11.98 & 20.15 & 25.78 & 34.23 & 51.45 & 60.34 \\
\hline 7 & $2 \mathrm{e}$ & 0.0 & 10.45 & 18.54 & 22.65 & 31.57 & 50.40 & 57.93 \\
\hline 8 & $2 f$ & 0.0 & 09.55 & 16.34 & 21.38 & 32.78 & 52.87 & 60.65 \\
\hline
\end{tabular}




\section{Pharmacology}

The vitro anti-inflammatory activity of the synthesized compounds was carried by protein denaturation method. An in-vivo anti-inflammatory activity was perfomed by using carrageenan induced paw edema method. Animals wistar rats (150-200 g) of either sex used in this study were purchased from the Animal House of the National Institute of Biosciences, Pune. The animals were maintained under standard laboratory conditions (12 h light/dark cycles at $22 \pm 2 \circ \mathrm{C}$ ) and fed standard rodent pellets (National Institute of Biosciences, pune, Maharashtra).All chemicals and solvents were procured from commercial sources, purified and dried using standard procedures from literature whenever required the reagents were purchased from Research laboratory Mumbai, MARCK laboratory Mumbai, S.D fine and issued from store department of Rajarambapu college of Pharmacy, Kasegaon. Melting points were determined by open capillary tube method and are uncorrected. Thin layer chromatography was used to assess the course of reaction and the purity of the

intermediate and the final compounds were confirmed by applying a single spot on TLC plate ( silica gel G ) using various solvents such as toluene, acetone system. TLC plates were visualized using iodine chamber. IR spectra were recorded using ATR JASCO FTIR- 4600. H1NMR spectra were performed in DMSO solution using Bruker $300 \mathrm{MHz}$ and their chemical shift are reported in $\delta$ unit with respect to TMS as internal standard. Mass spectra were recorded on Pesciex (model no. API 2000) software analyst 1.4.2 mode: Q1MS Q1/AUTO INJECTION from Diya Labs, Airoli, Mumbai.
4.1 General procedure for the synthesis of aroyl isothiocyanate:

A solution of aroyl chloride $(10 \mathrm{mmol})$ in acetone (50ml) was added dropwise to a suspension of potassium thiocyanate $(10 \mathrm{mmol})$ in acetone $(30 \mathrm{ml})$ and the reaction mixture was refluxed for $30 \mathrm{~min}$.

General procedure for the synthesis of $\mathrm{N}$ (phenylcarbamothioyl) benzamide derivatives:

After cooling to room temperature above product, a solution of the substituted aniline $(10 \mathrm{mmol})$ in acetone $(10 \mathrm{~mL})$ was added and the resulting mixture refluxed for 2-3 h. After completion of reaction (checked by TLC). The reaction mixture was poured into cold water and the precipitated $\mathrm{N}$ (phenylcarbamothioyl) benzamide derivatives were recrystallized from aqueous ethanol.

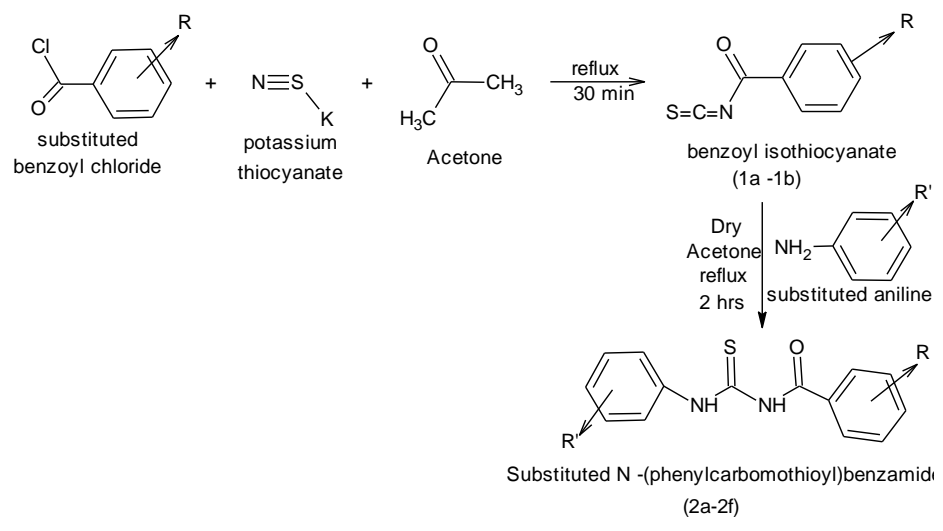

$\mathrm{R}=$ where, 2-chloro benzoyl chloride

\begin{tabular}{|l|l|l|l|}
\hline$R$ & & R & \\
\hline $\mathrm{R}$ &
\end{tabular}




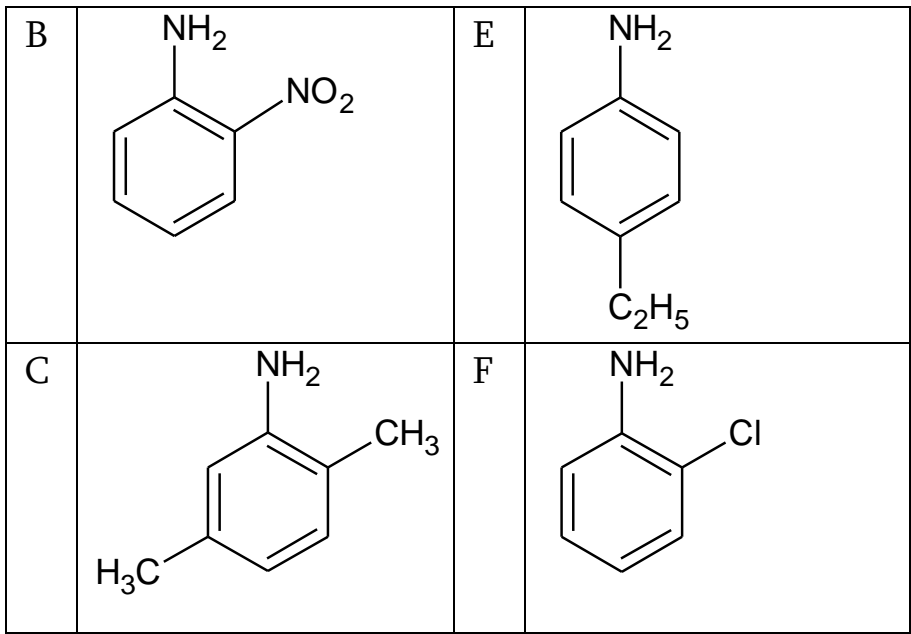

(2a). Synthesis of 2-chloro-N-[(4-chlorophenyl) carbamothioyl]benzamide:

This compound isolated as white solid with $75 \%$ yield, m.p. $127-129^{\circ} \mathrm{C}$; IR $\left(\mathrm{KBr} \mathrm{cm}{ }^{-1}\right): 3122$ (N-H-str.), 1675 (C=O), 1675 (Ar C-H str.) 1432 (C-NH), 1157 (C=S), 827 (C-Cl str.): 1H NMR (400MHz, DMSO-d6): 7.577.71 (3=CH 1-benzene, $1 \mathrm{C}(=\mathrm{O} \mathrm{N}, 1-\mathrm{Cl}) ; 7.71-7.74$ (2=CH (1-benzene, 1-Cl); 7.51-7.71 (3=CH (1benzene, $1 \mathrm{C}=\mathrm{O}) \mathrm{N}, 1-\mathrm{Cl})$; $3.28(1=\mathrm{C}-\mathrm{NH}$ aromatic); 12.02 ( $1=\mathrm{NH}$ sec amide): MS (m/z+)[M+] 325; For $\mathrm{C}_{14} \mathrm{H}_{10} \mathrm{Cl}_{2} \mathrm{~N}_{2} \mathrm{OS}$.

(2b). Synthesis of 4-chloro- $\mathrm{N}-[(3-$ nitrophenyl) carbamothioyl] benzamide:

This compound isolated as white solid with 75\% yield, m.p. $127-129^{\circ} \mathrm{C}$; IR $\left(\mathrm{KBr} \mathrm{cm}{ }^{-1}\right): 3158(-\mathrm{NH}-\mathrm{C}), 1691$ ( $\mathrm{C}=\mathrm{O}$ str.), 1585 (Ar C-H str.), 1425.14 (C-NH), 1155.15 (C=O str.): $1 \mathrm{H}$ NMR (400MHz, DMSOd6):7.87-7.92 (4=CH 1-benzene, $1 \mathrm{~N}(=\mathrm{O})=\mathrm{O}, 1-\mathrm{N})$, 7.48-7.55 4=CH ( 1-benzene, $1 \mathrm{C}=\mathrm{O}) \mathrm{N}, 1-\mathrm{Cl}$ ), 4.45 (1=C-NH aromatic), 12.62 (1=NH sec amide) : MS $(\mathrm{m} / \mathrm{z}+)[\mathrm{M}+]$ 335; For $\mathrm{C}_{14} \mathrm{H}_{10} \mathrm{ClN}_{3} \mathrm{O}_{3} \mathrm{~S}$.

(2c). Synthesis of 4-chloro-N-[(2,6-dimethylphenyl) carbamothioyl]benzamide:

This compound isolated as white solid with $68 \%$ yield, m.p. $133-135^{\circ} \mathrm{C}$;IR ( $\left.\mathrm{KBr} \mathrm{cm}^{-1}\right)$ : 3419 (C-NH str.), 1660 (C=O stretch), 1398 (C-CH3 bend), 1247(-NH-C), 755(C-Cl stretch) : $1 \mathrm{H}$ NMR $(400 \mathrm{MHz}$, DMSOd6):7.13-7.60 4=CH (1-benzene, $1 \mathrm{C}(=\mathrm{O}) \mathrm{N}, 1-\mathrm{Cl}), 8.02-$
$8.05 \quad$ (3=CH (1-benzene, 1-C, $1 \mathrm{~N}, 1-\mathrm{C}) \quad 7.60-$ 7.63(1= $\mathrm{CH}$ (1-C), 11.71-11.80 (1=NH (sec amide), 3.36 (1=C-NH ( aromatic ), 2.20 (1= CH3) : MS $(\mathrm{m} / \mathrm{z}+)[\mathrm{M}+] 318$; For $\mathrm{C}_{16} \mathrm{H}_{15} \mathrm{ClN}_{2} \mathrm{OS}$

(2d). Synthesis of 4-chloro-N-[(2,4-dinitrophenyl) carbamothioyl] benzamide:

This compound isolated as yellow solid with $80 \%$ yield, m.p. $122-124^{\circ} \mathrm{C}$; IR ( $\left.\mathrm{KBr} \mathrm{cm}^{-1}\right): 3384$ (-NH-C str), 1660 (C=O stretch), 1398 (Ar-NO2 asymmetric str.), 1288 (C-NH), 769 (C-Clstr) : 1H NMR (400MHz, DMSO-d6): 7.10-7.53 (4=CH (1-benzene, $1 \mathrm{~N}(=\mathrm{O})=\mathrm{O}$, $1-\mathrm{N})$, 7.86-7.93 (3=CH (1-benzene, 1-C $(=\mathrm{O}), 1-\mathrm{N})$, $3.46 \quad(1=\mathrm{C}-\mathrm{NH} \quad$ (aromatic), 8.11-8.12 $\quad(1=\mathrm{NH} \quad(\mathrm{sec}$ amide): $\mathrm{MS}(\mathrm{m} / \mathrm{z}+)[\mathrm{M}+]$ 380; For $\mathrm{C}_{14} \mathrm{H}_{9} \mathrm{ClN}_{4} \mathrm{O}_{5} \mathrm{~S}$

(2e). Synthesis of 2-chloro-N-[ethyl(phenyl) carbamothioyl] benzamide:

This compound isolated as brown solid with 65\% yield, m.p. $138-140^{\circ} \mathrm{C}$; IR $\left(\mathrm{KBr} \mathrm{cm}{ }^{-1}\right): 3365$ (-NH-C stretch), 1795 (C-NH stretch), 1685 ( $\mathrm{C}=\mathrm{O}$ stretch), 1317 (N-(CH3)2 bend), 755 (C-Clstr): 1H NMR (400MHz, DMSO-d6): 7.24-7.30 (4=CH (1-benzene, $1 \mathrm{C}(=\mathrm{O}) \mathrm{N}, \quad 1-\mathrm{Cl}), \quad 7.33-7.54 \quad(3=\mathrm{CH} \quad$ (1-benzene, $1 \mathrm{C}(=\mathrm{O}) \mathrm{N}, 1-\mathrm{Cl}), 7.19-7.21$ (2=CH (1-benzene, 1-N-C), 4.23-4.25 (1=CH2), 1.14-1.18 (1=CH3), 10.53 (1=NH sec amide): $\mathrm{MS}(\mathrm{m} / \mathrm{z}+)[\mathrm{M}+]$ 318: For $\mathrm{C}_{16} \mathrm{H}_{15} \mathrm{ClN}_{2} \mathrm{OS}$

(2f). Synthesis of 2-chloro-N-[(2-chlorophenyl) carbamothioyl] benzamide:

This compound isolated as white solid with $70 \%$ yield, m.p. $125-127^{\circ} \mathrm{C}$; IR ( $\left.\mathrm{KBr} \mathrm{cm}{ }^{-1}\right): 3124$ (N-H-str.), 1678 (C=O), 1679 (Ar C-H str.) 1435 (C-NH), 1158 (C=S), 829 (C-Cl str.): 1H NMR (400MHz, DMSO-d6): 7.677.70 (3=CH 1-benzene, $1 \mathrm{C}(=\mathrm{O} \mathrm{N}, 1-\mathrm{Cl}) ; 7.69-7.75$ (2=CH (1-benzene, 1-Cl); 7.50-7.72 (3=CH (1benzene, $1 \mathrm{C}=\mathrm{O}) \mathrm{N}, 1-\mathrm{Cl})$; 3.27 (1=C-NH aromatic); 12.03 (1=NH sec amide): MS $(\mathrm{m} / \mathrm{z}+)[\mathrm{M}+] 325$; For $\mathrm{C}_{14} \mathrm{H}_{10} \mathrm{Cl}_{2} \mathrm{~N}_{2} \mathrm{OS}$. 


\section{Anti-inflammatory evaluation:}

\section{a) In vitro Anti-inflammatory evaluation:}

Method: Evaluation of in vitro anti-inflammatory activity by protein denaturation Method (2a-f)

The mixture $(10 \mathrm{ml})$ consisted of $0.4 \mathrm{ml}$ of egg albumin (from fresh hen's egg), $5.6 \mathrm{ml}$ of Phosphate buffered solution (PBS, $\mathrm{pH}$ 6.4) and $4 \mathrm{ml}$ of varying concentration of test Samples so that final concentration become $50 \mu \mathrm{g} / \mathrm{ml}, 100 \mu \mathrm{g} / \mathrm{ml}$. similar volume of DMSO served as control. Then the mixtures were incubated at $(370 \mathrm{C} \pm 2)$ for $15 \mathrm{~min}$. and then heated at $70^{\circ} \mathrm{C}$ for $5 \mathrm{~min}$. After cooling, their absorbance was measured at $660 \mathrm{~nm}$ (JASCO UV Spectrophotometer) by using vehicle as blank and their viscosity was Determined by using Ostwald viscometer. Diclofenac sodium at the final concentration of $50 \mu \mathrm{g} / \mathrm{ml}, 100 \mu \mathrm{g} / \mathrm{ml}$ was used as reference drug and treated similarly for determination of absorbance and viscosity. The \% inhibition of protein denaturation was calculated by using the following formula,

$\%$ inhibition protein denaturation $=$ Absorbance of control- Absorbance of test

Absorbance of control

\section{b) In vivo-Anti-inflammatory screening of synthesized compound.}

Animals used Anti-inflammatory screening:

Animals wistar rats (150-200 g) of either sex used in this study were purchased from the Animal House of the National Institute of Biosciences, Pune. The animals were maintained under standard laboratory conditions (12 h light/dark cycles at $22 \pm 2{ }^{\circ} \mathrm{C}$ ) and fed standard rodent pellets (National Institute of Biosciences, pune, Maharashtra) and water. The protocol was approved by the Committee For The Purpose Of Control and Supervision of Experiments on Animals.

\section{In Vivo Anti-Inflammatory Activity (2a-f)}

Increase in the rat hind paw linear circumference induced by plantar injection was used as the measure of acute inflammation (Abimbola Sowemimo et, al., 1987). Were animals are divided into two groups of each as a standard, control and test (compound 2b2, 2a8). All these groups were kept for fasting overnight and only allowed water. The test rats $(n=6)$ were administered the synthesized compound $2 \mathrm{a}$ and $2 \mathrm{f}$ at dose $20 \mathrm{mg} / \mathrm{kg}$, p.o. While the standard rats received diclofenac $(10 \mathrm{mg} / \mathrm{kg}$ p.o.). One hour after treatment, $0.1 \mathrm{ml}$ of Carrageenan (1\%, w/v in normal saline) was administered into the sub-plantar tissue of the right hind paw. The linear paw circumference was measured immediately before injection and at $30 \mathrm{~min}$ interval for $4 \mathrm{hrs}$ using the cotton thread method (Bamgbose and Naomesi, 1981). Anti-inflammatory activity is determined by analyzing the reduction in edema size and calculating \% inhibition of edema. A mean reduction in edema when compared with control and an increase \% inhibition in the treated groups is an indication of anti-inflammatory activity. In vivo anti-inflammatory activity of compounds in Carrageenan induced rat paw edema assay $20 \mathrm{mg} / \mathrm{kg}$.

\section{CONCLUSION}

A series of novel substituted $\mathrm{N}$-(phenylcarbamothioyl) benzamide derivatives (2a-2f) was synthesized by microwave assisted reaction under green chemistry. The results of in vitro anti-inflammatory activity highlighted that tested compound $2 \mathrm{f}$ exhibited significant activity by protein denaturation method. The in-vivo anti-inflammatory activity was evaluated by carrageenan induced paw edema method and results highlight that compound $2 \mathrm{f}$ shows promising anti-inflammatory activity.

\section{ACKNOWLEDGEMENT}


I express my sincere thanks to Vice-principal Prof. Dr.

S. K. Mohite for providing me all necessary facilities and valuable guidance extended to me.

\section{REFERENCES}

[1]. Allison MC, Howatson AG, Torrance Cj, Lee FD, Russell IG., 1992. N Eng J Med. 327, 749754.

[2]. Bauer AW, Kirby W.W.M, Sherris J.C, Turck M., Clin Am. J., 1996. Pathol.45, 493.

[3]. Bekhit AA, Tarek AA., 2004. Bioorg Med Chem.12, 1935-1945.

[4]. Bhansali S, Kulkarni V., 2015. Der PharmaChemica. 7(1): 156.

[5]. Chopade A, Sayyad F, Naikwade N., 2014. Pharmacol Rep. 353-362.

[6]. Chopade A, Sayyad F., 2015. Phytother Res Int. 29, 1202-1210. 7Kalyoncuoglu N, Rollas S, Sur-Altiner D, Yegenoglu, Ang O., 1992. Pharmazie, 47, 769.

[7]. Husain A, Acad. J. Pharm., 2015 Jun; 4(3), 145152.

[8]. Ingle R, Inter J Pharm Res All Sci., 2012 Mar; 1(4), 46-51.

[9]. Raju G, Swathi K, Padma K, Sravani Y, Rao N., 2015. Asian J. Pharm. Sci. 3(1), 20-30.

[10]. Ranian K, Parmar S, Salzman S., 1998. J. Pharm. Sci. 78(12), 999-1002.

[11]. Rathore A, Sudhakar R, Ahsan M, Ali A, Subbarao N, Jadav S, Umar S, ShaharYar M., 2016. Bioorg Med Chem. 66, 1-35.

[12]. Ravindra KC, Vagdevi HM, Vaidya VP, Padmashali B., 2006. Indian J Chem B. 45, 2506-2511.

[13]. Sattu H, Inter J Pharm Sci Res., 2014 Dec; 5(12), 5201-5208.

[14]. Singh AK, Parthsarthy R, Lohani M., 2012. J Chem Pharm Res. 4, 779-782.
[15]. Sondhi M, Dinodia M, Singh J, Rani R., 2007. CurrBioact Compd. 3, 91-108.

[16]. Sowemimo A., Rev Bra de Farma., 2015 sept; 25(2), 506-512.

[17]. Talley JJ, Brown DL, Carter JS, Graneto MJ, Koboldt CM, Masferrer JL, Perkins WE, Rogers RS, Shaffer AF, Zhang YY, Zweifel BS, Seibert K., 2000. J Med Chem. 43, 775-777.

[18]. Vishwanathan B, B.M. Gurupadayya., 2015. Int. J. Pharm. 2, 41-51.

\section{Cite this article as :}

Akshay R. Yadav, Shrinivas K. Mohite, "Design, Synthesis and Characterization of Some Novel benzamide derivatives and it's Pharmacological Screening", International Journal of Scientific Research in Science and Technology (IJSRST), Online ISSN : 2395-602X, Print ISSN : 2395-6011, Volume 7 Issue 2, pp. 68-74, March-April 2020. Available at doi : https://doi.org/10.32628/IJSRST20723 Journal URL : http://ijsrst.com/IJSRST20723 